\title{
ИСТОРИЯ
}

БАГРИН Егор Андреевич,

канд. ист. наук, ведущий научный сотрудник научно-методической службы Президентской библиотеки имени Б.Н. Ельцина (г. Санкт-Петербург).

Электронная почта: egor-bagrin@yandex.ru

\section{Военные аспекты заключения Нерчинского договора в 1689 г.}

В статье, на основе документальных источников, рассматривается военное противостояние русских и маньчжуров в Нерчинске в 1689 г. во время ведения переговоров об установлении русско-китайской границы. В исследовании приведены подробные данные о военной «игре» обеих сторон, призванной оказать давление на оппонента, не доводя до открытого военного конфликта. Сделан вывод о том, что посол Ф.А. Головин эффективно реализовал потенциал своих сил, нивелировав численное преимущество войск империи Цин.

\section{Введение}

В 1689 г. в Нерчинске был заключен первый русско-китайский договор о границе. В историографии изучение различных аспектов, связанных с его появлением, наиболее ярко представлено монографиями и статьями, опубликованными в советское время. Работы П.Т. Яковлевой, В.С. Мясникова, Г.В. Мелихова, Е.Л. Беспрозванных и др. обстоятельно описали внутри- и внешнеполитические обстоятельства заключения договора, дипломатическую игру России и Китая, процесс переговоров, их результаты и значение $[1 ; 2 ; 7 ; 9 ; 10 ; 11 ; 12]$. В.С. Мясников отметил, что ни одна из сторон не хотела разрастания конфликта, возникшего в Приамурье, в полномасштабную войну. Маньчжуры не могли распылять силы, т.к. готовились к войне с правителем Джунгарии Галданом, а Россия противостояла Крымскому ханству. Кроме того, она не имела в Восточной Сибири достаточно сил для отражения агрессии Цинской империи. Маньчжуры не знали, сколько войск может выставить Русское государство. Однако осада Албазина показала, что помощь крепости не приходила в течение долгого времени. Это означало, что империя Цин имеет подавляющее военное превосходство в силах не только в Приамурье, но и, возможно, в Забайкалье. Обеим сторонам нужно было компромиссное решение. Однако военный фактор должен был сыграть решающую роль во время ведения переговоров [10, с. $278-279,297,302,312,332,351,353]$.

Условия мирного договора определялись военной «игрой», в которой каждая из сторон должна была продемонстрировать свои наиболее сильные стороны. В указанных нами работах эта «игра мускулами» отражена только в общих чертах. Нам представляется интересным проследить подробности этого процесса, которые и представлены в данной статье. Таким

русско-китайские отношения, Нерчинский договор, Ф.А. Головин, история, граница, Забайкалье, Дальний Восток

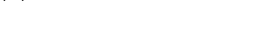

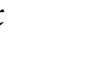


образом, предметом нашего исследования являются военные аспекты русско-китайского диалога в Нерчинске в 1689 г., а его целью оценка возможностей вооруженных сил России, задействованных в переговорном процессе, а также детальное отражение событийного ряда, связанного с военным противостоянием. Последнее позволит нам сделать выводы относительно эффективности предпринимаемых обеими сторонами действий и их влияние на ситуацию, складывающуюся вокруг переговоров. Источниковой базой исследования являются документы, опубликованные в сборнике «Русско-китайские отношения в XVII веке: материалы и документы. 1686-1691» с привлечением неопубликованных материалов, хранящихся в Российском государственном архиве древних актов.

Мы считаем, что предложенная в статье информация может быть актуальна в современное время, так как в отношениях между Россией и Китаем пограничный вопрос традиционно имеет большое значение, а его исторические и политические аспекты тесно переплетены. Поэтому результаты исследования могут быть применены при обосновании позиции России в рамках дискуссии, связанной с обсуждением характера договоров о границе с Китаем.

\section{Результаты работы}

Россия смогла привести в Забайкалье под руководством посла Ф.А. Головина не менее 1845 чел. В том числе 509 чел. московских стрельцов и военных специалистов, руководимых подполковником С. Богатыревым и полковником Ф. Скрипицыным (Московский полк), 1136 чел. из Тобольска, Тюмени, Томска, Енисейска, Илимска, Верхоленска, Нарыма, Кецка и Иркутска. Плюс около 200 вооруженных посольских людей, включая дворян, подъячих и их челядь, которых обычно не учитывают, рассматривая войско Ф.А. Головина. В войске было 20 пушек и мортира, более 1374 пудов пороха (вместе с тарой) и 490 пудов свинца. В сибирскую часть «посольского» войска, объединенного в два полка П. Грабова и А. Смаленберга, вошло более $10 \%$ всех сил, находящихся за Уралом. Однако качество этого военного контингента было неоднозначно, т.к. он более чем на 50 \% состоял из людей малоопытных в военном отношении: родственников служилых людей («дети, братья и племянники»), драгунов (по сути, крестьян, поселенных на границе) и новоприборных добровольцев из числа промышленных людей. Ударной силой были московские ратники и «окладные» служилые люди из сибирских крепостей. К моменту «посольского съезда» в Нерчинске несколько десятков участников похода (не более 100 чел.) были убиты в столкновениях с монголами под Удинском и Селенгинском и умерли от болезней. В гарнизонах Селенгинска, Удинска и Нерчинска было не менее 366 «коренных» служилых людей, плюс в Нерчинск из уезда собрались около 400 чел. промышленных людей и крестьян, взявших в руки оружие. В походе на табунутов вместе с русскими войсками сражались 300 конных воинов прибайкальских бурятов и тунгусов. Около 300 чел. могли выставить и нерчинские тунгусы. Таким образом, Ф.А. Головин располагал в Забайкалье более чем 3000 ратниками [4; 5; 6; 8] (РГАДА. Ф. 214. Оп. 3. Стб. 1059. Л. 157-158, 160, 274-278, 281-282, 290, 301-327).

Однако посол не мог собрать все эти силы к Нерчинску. Нужны были люди для обороны Удинска и Селенгинска, небольшое число 
войск пополнило Албазинский гарнизон, численность которого к лету 1689 г. составила около 200 ратников [3]. Воины прибайкальских бурятов и тунгусов не отходили далеко от своих кочевий, где они оберегали свои семьи, поэтому Ф.А. Головин мог рассчитывать только на тунгусов Нерчинского уезда. Помощи ждать было не откуда. «Посольское» войско добиралась до Забайкалья 1 год и 4 месяца, имея в пути проблемы с транспортировкой и продовольствием. Государственный ресурс по обеспечению продвижения войск с запада на восток в значительной мере был исчерпан. В тоже время у Ф.А. Головина были сведения о приближении к Нерчинску значительных сил маньчжуров [5; 6].

29 апреля 1689 г. посол разослал приказы по полкам немедленно готовиться к походу в Нерчинск. Из Иркутска в конце мая прибыли необходимые хлебные запасы. Кроме того, служилые люди полка А. Смаленберга отправились на заимки, чтобы взять хлеб у местных жителей «по переписке». Буряты, живущие у Байкала, обязывались прислать 240 лошадей. «Новые выходцы» табунуты должны были прислать 90 подвод, а монголы - 60. Полученный гужевой транспорт был распределен по полкам для перевозки пушек и боевых припасов. 24 июня 1689 г. войско вышло из Удинска в Нерчинск. В крепости остался капитан московских стрельцов Сава Володимеров и 120-150 чел. «московских и сибирских розных полков стрельцов». 10 июля 1689 г. полки дошли до Еравнинского острога, где задержались на 3 дня изза «худобы» лошадей. Дорога была трудная, т. к. шли «превеликими грязьми и болотами», местами телеги с хлебом служилые переносили сами. Первым шел посол с московскими стрельцами, за ним, отставая на 2 дня, полки П. Грабова и А. Смаленберга. 4 августа 1689 г. силы Ф.А. Головина собрались на плотбище и стали сплавляться на плотах по 12 и больше человек на каждом плоту. Пушки, боеприпасы и хлеб перемещались таким же способом, т. к. лошади не могли перевезти грузы горами («каменем»). Федор Стахорский, капитан полка П. Грабова, и капитан Московского полка Богдан Булгаков вместе с 80 ратниками погнали конные табуны по суше [11, с. 441-442, 451, 456, $465,468,471,609-610]$.

В это время к Нерчинску подошли маньчжурские войска для «посольских договоров и успокоения ссор и разграничения земель и вечнаго мира». Они стояли в дневном переходе от крепости на р. Макарьеве. 18 июля 1689 г. нерчинский воевода И. Власов послал к ним Л. Нейтера, прапорщика полка П. Грабова, и 20 чел. служилых людей. Вернувшись, они сообщили, что у китайцев около 5000 чел. и 10 небольших пушек вокруг посольского стана. Позже нерчинские казаки доложили, что в китайском войске 45 полковых пушек, привезенных на кораблях, 10 небольших орудий, доставленных по суше, 1 пудовая мортира и небольшое число ратников с ручным огнестрельным оружием. В Нерчинске к этому моменту было около 600 чел., включая промышленных людей и пашенных крестьян. Получив об этом сведения, Ф.А. Головин послал в Нерчинск пятидесятника московских стрельцов Степана Терентьева и 16 новоприборных иркутских стрельцов. Терентьев должен был передать приказ, отправить к нерчинским ясачным людям «язычного» человека, чтобы они шли в «легких людях» к посольскому войску, спрятав свои семьи, табуны и скот в «крепких местах». К послу приехало 30 нерчинских ясачных 
1 Надолбы - защитное coоpужение, представляющее собой заостренные бревна, вкопанные в землю прямо или под углом (острием в сторону возможного нападения противника). Дополнительно могли соединяться между собой бревнами перемычками. Надолбы препятствовали подходу к стенам крепости вражеской кавалерии и осадных машин. тунгусов, 20 из которых отправились помочь передвижению конных табунов [11, с. 466-467, 473, 558].

Таким образом, «первый раунд» переговоров остался за Китаем. Для Ф.А. Головина стало очевидно, что маньчжуры могут быстрее и эффективней подвести войска в восточное Забайкалье. Солдат и артиллерии у них было больше чем в 2 раза, а возможность получить подкрепление на кораблях из Айгуня не шла ни в какое сравнение с тяжелым путем «посольского войска». Кроме того, резерва у посла просто не было.

Китайские представители вышли на нескольких кораблях на встречу Ф.А. Головину и встретили его на месте, где от слияния рек Онон и Ингода образуется р. Шилка. Посол пытался договориться о паритете вооруженных людей с обеих сторон во время переговоров. В это время «на стойке» стояли 200 московских стрельцов, а остальные войска находились у плотов, так что за лесом их не было видно. 7 августа 1689 г. в урочище Верблюжье Горло в 20 верстах от Нерчинска к войску пришел конный табун. Пушки и боеприпасы погрузили на телеги и отправили в Нерчинск вместе с основными силами. Навстречу послу пришел сын нерчинского воеводы Ивана Власова Петр с 200 ратниками и 300 ясачными тунгусами. Онкоты и буряты своих людей не дали. Хлебные припасы временно оставили на месте под охраной майора Якова Петерсона, 2 капитанов и 300 чел. служилых людей. Войска пришли в Нерчинск 9 августа 1689 г. Затем 200 чел. московских стрельцов отправились к плотам с хлебом. Полковники с остальными ратниками подошли к устью р. Нерчи для приема грузов [11, с. С. 492, 494].

При осмотре Нерчинского острога Ф.А. Головин отметил, что он «зело плох», «гораздо мал и худ, и многие бревна подгнили, и к воинскому промыслу был безнадежен». Для встречи китайских послов на площади перед крепостью были «разбиты 2 намета». У них поставили по 120 чел. ратников и 12 пушек. При осмотре китайского лагеря численность прибывших китайцев выяснить не удалось. Основной лагерь стоял 9-ю «городками», часть воинов стояла на горах. Рядом были бусы с пушками, которые были прикрыты, так что пересчитать их было нельзя. Ф.А. Головин предложил встретиться для переговоров в 100 саженях от надолбов ${ }^{1}$ нерчинской крепости вниз по р. Шилке. С обеих сторон иметь по 300 чел. без огнестрельного оружия только с саблями, сулемами, бердышами и копьями. Китайские корабли 30 бус, перевозящие свою делегацию на «съезжее место», должны были встать от него в 300 саженях, а люди на них - 500 чел. не должны были сходить на берег. Китайцы хотели знать, сколько войска находится в Нерчинске, чтобы расположить такое же число воинов, на равном расстоянии от места переговоров. Кроме того, на высоких местах вокруг места встречи должны были встать по 10 чел. караульщиков [11, с. $494-495,497-498,500-501,537]$.

Дворянин В. Лутовинов и селенгинский сын боярский Д. Многогрешный, капитан и 40 стрельцов выбрали место для посольского съезда в 200 саженях от Нерчинска у р. Нерчи. Здесь невозможно было заметить "прикрытых людей" с китайской стороны, т.к. "близ по Шилки тальники и водомойны великие", однако «иного съезжего места выбрать было близ Нерчинска на поле негде». Поручик полка А. Смаленберга Микита Касимов и 15 нерчинских казаков размести- 
лись на сопках, чтобы предупредить выстрелами, если к китайцам во время переговоров придут «прибавочные люди». Д. Многогрешный вместе с отрядом ратников осмотрел место высадки китайцев и донес, что на берег вышли и встали в тальнике больше 700 чел. Поручик полка П. Грабова Василий Волошенин съездил в китайский лагерь и привез в Нерчинск иезуитов, бывших в цинском посольстве. Через них китайскую сторону попросили придерживаться договоренностей. Прапорщик Л. Нейтер руководил караулом, смотревшим за местом перевоза китайских делегатов через реку, а поручик В. Волошенин за «посольскими наметами» ночью [11, с. 500-502, 504, 514, 519, 532].

Можно считать, что второй «раунд» военной «игры» у Нерчинска остался за русской стороной. Ф.А. Головин смог умело скрыть от маньчжуров численность своего войска, оставив их в неведении относительно того, действительно ли они имеют какое-то военное преимущество. Это важный момент, который влиял на позиции «партии войны» в маньчжурском посольстве, усиливая сторонников решения проблемы мирным путем, в том числе посредством уступок. В то же время посол продемонстрировал выучку московских стрельцов и полковую артиллерию - «грозную силу», пришедшую от русского царя, с которой «богдойским» генералам еще не приходилось сталкиваться, и это также лишало их уверенности. Кроме того, Головин выстроил действенную систему обеспечения безопасности посольской встречи.

Во время переговоров с представителями империи Цин с Ф.А. Головиным были 200 чел. дворян, подъячих и другие «посольские люди» и их сопровождение. Охраняли посольство полковник Ф. Скрипицын, подполковник С. Богатырев и московские стрельцы 300 чел. с саблями, бердышами, копьями и «гранатными ручными ядрами», взятыми для «опасности». Полки П. Грабова, А. Смаленберга и часть московских стрельцов стояли в Нерчинске, приготовившись в случае опасности к атаке под руководством полковника А. Смаленберга, майора Якова Петерсона и капитана московских стрельцов В. Ресина. Стенные караулы вокруг слобод были усилены 300 стрельцами с начальными людьми [11, с. 500-502, 504, 521].

В ходе многодневных переговоров Ф.А. Головин получил сведения о том, что брацкие и онкотские люди, связавшись с китайцами, «изменили» и, приготовив около 2000 воинов, вынашивают планы нападения на Нерчинск. Китайцы предлагали им свои корабли, чтобы перейти р. Шилку, а также просили их отогнать от острога скот и конные табуны нерчинских жителей. Посол написал в отчете, что к этому моменту он располагал только 1450 ратниками, включая нерчинских служилых людей, промышленных людей и пашенных крестьян, собравшихся в крепость со всех заимок Нерчинского уезда. Однако, вероятно, Ф.А. Головин преуменьшил или не учел часть своих сил, оправдывая перед правительством отсутствие активных действий по отношению к изменникам. По нашим данным, с учетом потерь и людей, оставленных в Селенгинске и Удинске и отправленных в Албазин, его силы в Нерчинске должны были быть около 2000 ратников. Чтобы получить больше информации, посол приказал выяснить места перехода р. Шилки посыльными изменников и захватить их. Одно из таких мест было обнаружено отъезжей станицей, и на этом месте была устроена засада из 30 казаков под началом Д. Многогрешного. Однако они не смогли никого захватить. Ясачные тунгусы, верные русским 
(300-400 юрт), стояли в дневном переходе от острога в «крепких местах». Они так же ждали нападения бурятов и онкотов [11, с. 524, 529, 531-532, 534].

20 августа 1689 г. Л. Нейтер и его караул заметили скопление китайского войска в одном месте. Подьячий И. Логинов и Д. Многогрешный отправились к перевозу для «проведывания», и подтвердили эту информацию. Сверху и снизу р. Шилки в китайский лагерь прибыли около 500 конников. На бусах работники с топорами начали что-то делать, возможно, станки для пушек. Для того, чтобы выяснить всё в точности, нерчинскому казаку Семену Молодому приказали как бы случайно проплыть рядом с кораблями. В это же время нерчинский казак Карпушка Уской из отводного караула на сопке доложил, что к цинскому табору подходят многие воинские люди с табунами [11, c. 532-533].

21 августа 1689 г. китайцы свернули лагерь и, перейдя реку, 3000 чел. в куяках со знаменами встали вокруг Нерчинска на горах, поставив палатки всего в полуверсте от крепости. Табор цинских послов теперь находился недалеко от Нерчинска под охраной 1000 чел. Также в поле рядом с острогом на дорогах разместились китайские караулы по 100 чел. К ним присоединились брацкие и онкоцкие изменики в куяках. Китайцы объяснили свои действия тем, что перешли Шилку для «конских кормов», а караулы призваны удерживать «измеников» от нападения на русских. В ответ Ф.А. Головин приказал сделать вокруг Нерчинска тройные надолбы и окоп и вышел за них со стрелецкими полками «в готовности». После возведения надолбов, в этот же день срочно стали строить «малый город» из бревен плотов, на которых войско прибыло в Нерчинск. Ясачным тунгусам было приказано откочевать к Теленбинскому острогу [11, с. 536-538, 558].

Эта фаза противостояния, являвшаяся следствием неуступчивости обеих сторон во время переговоров, очень интересна. Соперники «раскрыли карты» и по инициативе китайской стороны продемонстрировали друг другу свои возможности. На наш взгляд, выбранная $Ф . А$. Головиным тактика, нивелировала численное преимущество китайского войска. Посол не бросил все силы на укрепление Нерчинска, чтобы отражать нападение за его стенами. В этом случае он, наверняка, повторил бы печальную участь Албазинской крепости, разгромленной в 1685 году маньчжурской осадной артиллерией за несколько часов. Русские войска, развернувшиеся перед городом, поставили противников в затруднительное положение. Атаки маньчжурской и бурятской конниц на правильные построения, тем более усиленные пушками и полевыми укреплениями, были обречены на поражение. Это показал победный опыт боев у Удинска и Селенгинска в 1688 г., где «посольским» полкам противостояли лучшие всадники монгольского Батур-контайши. Отметим также фактор того, что войско Ф.А. Головина было поголовно вооружено ручным огнестрельным оружием, противостоять которому в открытом полевом бою не могла многочисленная китайская пехота, имевшая только холодное оружие и луки со стрелами. «Богдойская» артиллерия находилась на кораблях, а русская была уже изготовлена к бою. Таким образом, Ф.А. Головин не только показал, что он готов начать сражение, он реально поставил соперников в ситуацию, когда они, начав агрессивные действия в момент эскалации конфликта, могли потерпеть поражение. 
22 августа 1689 г. ${ }^{2}$ китайцы устроили переправу бурятов и онкотов через р. Нерчу. Ф.А. Головин отметил, что таким образом цинские войска, заполучив скот «изменников», решили продовольственную проблему. До этого им из-за недостатка припасов, приходилось покупать скот у нерчинских жителей «дорогой ценой». Из-за малочисленности конницы, число которой с учетом сибирских и нерчинских ратников «конного списка», а также посольской челяди не превышало 400-500 чел., русские войска не могли препятствовать переходу «изменников». В это же время последними был захвачен и иссечен на части один из нерчинских казаков, искавший верблюда. Посол решился и выслал к перевозу на р. Нерчу 100 чел. под началом поручика Василия Волошенина и Д. Многогрешного. Они должны были уговорить перебежчиков вернуться или «учинить над ними воинский промысел». Буряты и онкоты, застигнутые в урочище Сажиковый Яр, не стали «перекликаться» и начали стрелять из луков. Произошла стычка, в которой русскими были захвачены 3 языка. В этот же день больше 2000 «изменников» в куяках встали в 1,5 версте от Нерчинска вместе с китайскими караулами, число которых увеличилось. Ф.А. Головин снова вывел из крепости стрелецкие полки, а сам вышел с конницей, но до боя дело не дошло. 25 августа 1688 г. стало известно, что нерчинские ясачные тунгусы князя Гантимура атаковали бурятов и онкотов при переправе и не дали им перейти Нерчу. На следующий день остановить перебежчиков на р. Шилке, отправились 400 служилых людей под командованием капитана полка П. Грабова Федора Стахорского и поручика полка А. Смаленберга Никиты Касимова. В 7 верстах от Нерчинска на р. Шилке произошел большой бой и «напуски великие». В схватке русские потеряли 26 чел. убитыми среди служилых и промышленных людей, многие ратники были ранены, в том числе капитан и поручик. При осмотре поля боя были найдены больше 100 чел. убитых бурятов и онкотов, при этом многие тела «побитых по лесам розвели мунгальские люди». 30 августа 1689 г. уже после подписания Нерчинского договора отряд вернулся в крепость [11, с. 539-541, 558, $573,600]$.

Учитывая эти обстоятельства, мы можем считать, что Ф.А. Головин, после того как показал маньчжурам, что готов померятся с ними силами, почувствовал уязвимость их положения в данный конкретный момент. Следствием уверенности в том, что китайская сторона не решиться вмешаться, стали атаки на перебежчиков. Таким образом, инициатива в военной «игре» перешла на сторону России, но посол прекрасно понимал всю сиюминутность этого положения. К «богдойцам» подходило подкрепление, а к русским нет. Нужно было завершать переговоры пока превосходство противника в живой силе не станет критическим.

Ф.А. Головин нуждался в информации о численности неприятеля. Разведчики 20 чел. и сын боярский Логин Матвеев, выйдя из острога, наткнулись у перевоза на китайские караулы и возвратились назад. Позднее два промышленных человека сумели осмотреть китайское войско с «каменных гор из дальних мест». Они сообщили, что главный китайский лагерь стоит на другой стороне р. Шилки и в нем больше 10000 чел. Подьячий Панкрат Бабаев, ездивший для прояснения ситуации в посольский стан китайцев, нашел его в урочище Ключи в 3 верстах от Нерчинска. Он сообщил, что по его прикидке, в цинском
2 В это время 21 августа 1689 г. под Албазин подошли китайские корабли и конница, которая сожгла и вытоптала «сжатый и несжатый» хлеб под крепостью. В августе же 1689 г. из-под Селенгинска ушел тайша Ирдени Цохта и 50 чел., принявшие до этого русское подданство. Беглецы были настигнуты лучшими людьми тайши ИрдениКонтазия, сохранявшего верность. Между ними был бой на р. Чикой, после чего Ирдени Цохта сумел с несколькими людьми уйти в «крепкие места» [11, с. 608]. 
войске по обе стороны реки около 12000 чел. Основная часть из них стояла в палатках 9-ю городками, 300 чел. было с пищалями. Пушек, о которых до этого доносили нерчинские казаки, он не видел. Даже при всей приблизительности этих данных было понятно, что цинские войска имеют существенный перевес сил. Кроме того, нерчинские казаки донесли о наличие в них монгольской конницы. 500 чел. монголов охраняли место переправы. От бескормицы в Нерчинске начался падеж скота и лошадей, согнанных русскими для безопасности в слободы. Караулы в Нерчинске увеличились до 500 чел. Все эти сведения естественно подталкивали Ф.А. Головина к быстрейшему окончанию «посольского съезда» и уступке того, что было разрешено правительством. Переговоры завершились 29 августа 1689 г. Договор о границах между Китаем и Россией был подписан в «великих наметах» в 50 саженях от надолбов. Со стороны русских послов у места соглашения стояли строем 400 московских стрельцов, а со стороны китайцев на горе в версте от Нерчинска около 5000 конных воинов. После подписания документов произошел обмен договорными письмами. За Ф.А. Головиным были 100 чел. дворян и других посольских людей, 200 конных нерчинских казаков, полковники П. Грабов и А. Смаленберг и 50 пеших ратников из их полков. У места стоял Московский полк с некоторым количеством сибирских служилых людей «в поддачю». За китайскими послами были около 5000 чел. «в куяках и в саадаках» и «12 знамен больших, на иных писано и на иных шито золотом змеи великие, а кругом тех знамен обшиты мохры шелковые и пришиты кисти большие красные. Да малых еловчиков при тех же знаменах было со 100 или больши». Поручик полка П. Грабова В. Волошенин проводил китайских послов до бус с фонарем. 31 августа 1689 г. китайское посольство на кораблях и степью ушло от Нерчинска. Прапорщик Л. Нейтер, сын боярский М. Сенотрусов и 10 служилых людей были отправлены Ф.А. Головиным для помощи продвижению китайской делегации до урочища Уручки в 12 верстах от Нерчинска, где находились последние заимки Нерчинского уезда [11, с. 539-542, 558, 582, $599,604,607]$.

В этот же день в поход на бурятов и онкотов был послан отряд 600 чел. под руководством селенгинского сына боярского Д. Многогрешного. «Изменники» не пошли на переговоры и стали стрелять, после чего произошел бой, завершившийся удачей для русских. Многие из перебежчиков были «побиты», их жены и дети, «конные и скотные табуны» захвачены. Часть кочевников ушла в степь и затем на землю, контролируемую китайцами на р. Кулюрюн у озера Далай, а 200 юрт стали кочевать у Нерчинска, отказавшись от ухода из русского подданства [11, с. 604, 607, 613].

Таким образом, военная «игра» завершилась удовлетворением обеих сторон. Маньчжурские чиновники и генералы отвели от себя риск потерпеть неудачу в столкновении с русскими и впасть в немилость императора, а Ф.А. Головин не начал конфликт, в котором даже в случае первоначального локального успеха, он был бы обречен на поражение вследствие отсутствия возможности получить подкрепление. Маньчжуры понимали этот момент. В ходе переговоров иезуиты, представлявшие китайскую сторону, отметили, что они «наслышались от изменников руских людей ... каково споможение даурским острогом чинить трудно руским людем за дальностию пути». На это 
Ф.А. Головин ответил что из «Тобольска скорым ходом мочно ранее 4 месяцев поспеть ратным людем в Даурскую землю». Он добавлял, что если случится вести войну с Китаем, то «безо всякой трудности не то, что с Москвы, и из сибирских городов ратных людей множество привести мочно в Даурскую землю» [11, с. 602]. Оба утверждения посла объективно были далеки от правды. Его переход в Забайкалье из Тобольска занял 1 год и 4 месяца. Гарнизоны сибирских крепостей, имели минимальное число ратников, и их дальнейшее ослабление могло негативно сказаться на безопасности всех сибирских владений России.

По результатам договора А. Бейтон «разорил» Албазинскую крепость - раскопал при китайских представителях вал и сжег все деревянные постройки, после чего пришел в Нерочинск со всеми ратниками, мирными жителями, оружием и боеприпасами. Аргунский острог должен был быть перенесен на другую сторону реки, но так как в нём было только 20 чел., то эту работу перенесли на следующий год [11, с. $608,612-613]$.

Руководствуясь царским приказом, посол усилил гарнизон Нерчинска 200 конными служилыми из «сибирских» полков и усилил крепостные сооружения. На старом острожном месте полковые стрельцы возвели новую деревянную крепость: «одна стена длиною 90 сажен, 2 стены по 70 по 6 сажен, а вышиною стены по 3 сажени; да 2 проезжие башни вышиною до обламов по 3 сажени, шириною по 4 сажени, 3 наугольных». 15 октября 1689 г., достроив город, Ф.А. Головин с войском вышел из Нерчинска в Удинск. 28 октября они пришли в Телембинской острог, а 5 ноября в Еравинский острог. Лошади и верблюды «за худобой» и усталостью были оставлены под присмотром в степи на хребтах и дороге, так что часть пути до Еравинска служилые люди шли пешком, перенося на себе полковые и хлебные припасы. В Удинский острог полки пришли 14 ноября 1689 г. ${ }^{3}$ Буквально на следующий день, 15 ноября 1689 г., 100 конных стрельцов вышли в Селенгинск на соединение с 200 ратниками, которые должны были атаковать Катаг-Батур тайшу, угнавшего лошадей и скот у «нового выходца» монгольского тайши Ирки-Контазия. В конце декабря 1689 г. и сам Ирки-Контазия тайша откочевал от русского подданства в Монголию к «немирным тайшам». Ф.А. Головин приказал ясачным бурятам и «табунуцким выходцам» быть готовыми к походу. В связи с постоянным напряжением на границе с монгольскими землями посол увеличил гарнизоны приграничных крепостей, в т.ч. введя в их штаты казаков «конной службы». Однако следует отметить, что эти изменения, имея важность для борьбы с набегами кочевников, не играли бы почти никакой положительной роли в случае вероятной войны с Китаем. Для этого людей в Забайкалье было слишком мало. 18 февраля 1690 г. Ф.А. Головин перешел в Иркутск, откуда 18 мая 1690 г. вместе с Московским полком отправился по направлению Москвы. Вместе с ним поехали полковники П. Грабов и А. Смаленберг и их офицеры. «Сибирские» служилые люди остались до государственного указа в Удинске и Селенгинске. 19 июня 1690 г. посол и остальные люди пришли в Енисейск, 27 июля 1690 г. в Нарым, 9 августа 1690 г. в Сургут и 6 сентября 1690 г. в Тобольск, а затем оттуда вернулись в Москву [11, с. 616-619].
1 В другом месте 16-го ноября 1689 г. Московский полк, посольская свита и 835 чел. из сибирских полков 


\section{Выводы}

Подводя общий итог, отметим:

В период проведения переговоров вооруженные силы России не были готовы к ведению конфликта с Цинской империей в Забайкалье и Приамурье. Численность войск, расположенных в Даурии, была слишком мала для войны с сильным государством. Они были оторваны огромным расстоянием от основных сил и баз снабжения, расположенных в Европейской части России и Сибири. В то же время несовершенные транспортные коммуникации и система обеспечения продовольствием не позволяли быстро перемещать большое число ратников с западных областей страны на Дальний Восток. Кроме того, укрепленные пункты, расположенные в Забайкалье, не были готовы противостоять осадной артиллерии, бывшей на вооружении маньчжурской армии. Китай, напротив, имел возможность обеспечить своим войскам численное преимущество и быстро пополнять силы своего военного контингента, направленного к Нерчинску. Не менее важным обстоятельством было то, что маньчжуры имели сведения о проблемах российской стороны. Пользуясь этим обстоятельством, они старались навязать выгодные для себя условия установления границы с Россией, не считаясь с ее предложениями и требованиями.

Ф.А. Головин, учитывая описанные обстоятельства, принял исключительно смелое решение. Он не стал делать ставку на возможность отсидеться за стенами Нерчинского острога, что неминуемо в случае боевых действий привело бы русскую сторону к поражению. Посол долгое время умело скрывал общее число и качество своих войск, что лишало уверенности «партию войны» в китайской делегации. В критический же момент Ф.А. Головин продемонстрировал «богдойской» стороне то, что в случае эскалации конфликта его войска готовы к открытому полевому сражению. Московские и сибирские стрельцы, вооруженные огнестрельным оружием и опиравшиеся на полковую артиллерию, реально имели значительные шансы победить атакующую их маньчжурскую конницу и пехоту. Более того, в критический момент противостояния китайская артиллерия оставалась на кораблях, а русская находилась в полной готовности в эпицентре разворачивавшихся действий. Таким образом, Ф.А. Головин сумел поставить своих оппонентов в такое положение, в котором им было крайне не выгодно инициировать военное столкновение. Вероятность потерпеть локальное поражение в сражении под Нерчинском привела к тому, что «богдойские» чиновники, боявшиеся «потерять лицо» перед императором Поднебесной, настояли в своем лагере на варианте компромиссного договора с учетом интересов России. Между тем и посол, осознававший бесперспективность затяжного конфликта с «богдойцами», с учетом того, что к ним постоянно прибывали свежие силы, был вынужден согласиться на вывод русских с территории Приамурья. Кроме того, отметим, что Ф.А. Головин, пользуясь достигнутой в переговорах инициативой, не упустил возможности атаковать племена онкотов и бурятов, договорившихся с китайской стороной о переходе их под ее покровительство. Этот удар застал кочевников врасплох. Часть из них под воздействием победы русских вернулась к Нерчинску. 
Таким образом, подводя итоги военных «игр» у Нерчинска, заметим, что Ф.А. Головин, находясь в крайне невыгодных условиях, сумел полностью реализовать потенциал вверенного ему военного контингента, перехватив инициативу у более сильного противника. В заключение отметим, что конфликт с Китаем на восточных рубежах стал отправной точкой для формирования концепции оборонной политики России на Дальнем Востоке. Дальнейшее изучение деталей этого процесса может быть полезным для понимания дальнейших государственных мер по защите русских границ в этом регионе.

\section{Литература}

1. Александров В.А. Россия на дальневосточных рубежах (вторая половина XVII в.). Хабаровск: Хабаровское книжное издательство, 1984. 272 с.

2. Артемьев А.Р. О некоторых спорных вопросах пограничного размежевания между Россией и Китаем по Нерчинскому договору 1689 г. // Вестник Дальневосточного отделения Российской Академии Наук. 2002. № 1 (101). С. 7-22.

3. Багрин Е.А. Гарнизон Албазинской крепости в 1687-1689 гг. // Гуманитарные исследования в Восточной Сибири и на Дальнем Востоке. 2020. № 3(53). С. 93-105.

4. Багрин Е.А. Сибирские «выборные» служилые люди в полку Ф. Головина в 1686-1690 гг.: численность и состав (с поименным списком) // Известия Лаборатории древних технологий. 2020. Т. 16. № 2. C. $90-119$.

5. Багрин Е.А. Сибирские полки во время похода Ф.А. Головина в Даурию. 1 часть: переход Тобольск-Удинск (16861687 гг.) // Известия Лаборатории древних технологий. 2020. Т. 16. № 3. С. 162-174.

6. Багрин Е.А. Сибирские полки во время похода Ф.А. Головина в Даурию.

2 часть: Военные действия в Забайкалье (1687-1688 гг.) // Известия Лаборатории древних технологий. 2020. Т. 16. № 4. C. 129-144.

7. Беспрозванных Е.Л. Приамурье в системе русско-китайских отношений, XVII - середина XIX в. М.: Наука, 1983. $206 \mathrm{c}$.

8. Леонтьева Г.А. Служилые люди в Восточной Сибири во второй половине XVII - первой четверти XVIII в. (по материалам Иркутского и Нерчинского уездов). М., 2012. 321 с.

9. Мелихов Г.В. Маньчжуры на северо-востоке Китая (XVII в.). Москва: Наука, 1974. $246 \mathrm{c}$.

10. Мясников В.С. Империя Цин и Русское государство в XVII в. Хабаровск: Хабаровское книжное издательство, 1987. $512 \mathrm{c}$.

11. Русско-китайские отношения в XVII веке: материалы и документы. 1686-1691 / сост. Н.Ф. Демидова, В.С. Мясников. М.: Наука, 1972. Т. 2. 835 с.

12. Яковлева П.Т. Первый русско-китайский договор 1689 года. М.: Издательство Академии наук СССР, 1958. 213 с.

Egor A. BAGRIN,

Ph.D (in History), Researcher of the Scientific and Methodological Department, Boris Yeltsin Presidential Library (Saint-Petersburg, Russia)

E-mail: Egor-bagrin@yandex.ru

\section{Military Aspects of Nerchinsk Treaty Conclusion in 1689}

UDC 94(47).048 DOI https://doi.org/10.24866/2542-1611/2021-3/49-60 
Russian-Chinese relations, The article, based on documentary sources, examines the Treaty of Nerchinsk,

F.A. Golovin,

XVII century,

history,

border,

Transbaikalie military confrontation between the Russians and the Manchus in Nerchinsk during the negotiations concerning RussianChinese border establishment in 1689 . The study provides detailed data on "war game" of both sides, aimed to put pressure on the opponent, without leading to an open military conflict. China had an advantage in transport communications and in number of military forces that were transferred to the place of negotiations. However, during the aggravation between the negotiators Fyodor Golovin, Russian ambassador, withdrew his troops for a field battle, in which he could use the hand-held firearms and artillery advantage of his troops instead of fortress defense tactics. Thus he realized effectively the potential of his forces, leveling the numerical advantage of the Manchus. This moment influenced the course of negotiations, persuading Chinese diplomats to abandon several unacceptable demands for Russia.

For citation: Bagrin E. A. Military aspects of Nerchinsk Treaty conclusion in 1689 // Oriental Institute Journal. 2021. № 3. P. 49-60. DOI https://doi.org/10.24866/2542-1611/2021-3/49-60

\section{References}

1. Aleksandrov V.A. Rossiya na dal'nevostochnykh rubezhakh (vtoraya polovinaXVII v.).KHabarovsk: KHabarovskoe knizhnoe izdatel'stvo, 1984. 272 s.

2. Artem'ev A.R. O nekotorykh spornykh voprosakh pogranichnogo razmezhevaniya mezhdu Rossiej i Kitaem po Nerchinskomu dogovoru 1689 g. // Vestnik Dal'nevostochnogo otdeleniya Rossijskoj Akademii Nauk. 2002. № 1 (101). S. 7-22.

3. Bagrin E.A. Garnizon Albazinskoj kreposti v 1687-1689 gg. // Gumanitarnye issledovaniya v Vostochnoj Sibiri i na Dal'nem Vostoke. 2020. № 3(53). C. 93-105.

4. Bagrin E.A. Sibirskie «vybornye» sluzhilye lyudi v polku F. Golovina v 16861690 gg.: chislennost' i sostav (s poimennym spiskom) // Izvestiya Laboratorii drevnikh tekhnologij. 2020. T. 16. № 2. S. 90-119.

5. Bagrin E.A. Sibirskie polki vo vremya pokhoda F.A. Golovina v Dauriyu. 1 chast': perekhod Tobol'sk-Udinsk (1686-1687 gg.) // Izvestiya Laboratorii drevnikh tekhnologij. 2020. T. 16. № 3. S. 162-174.

6. Bagrin E.A. Sibirskie polki vo vremya pokhoda F.A. Golovina v Dauriyu. 2 chast':
Voennye dejstviya v Zabajkal'e (1687-1688 gg.) // Izvestiya Laboratorii drevnikh tekhnologij. 2020. T. 16. № 4. S. 129-144.

7. Besprozvannykh E.L. Priamur'e v sisteme russko-kitajskikh otnoshenij, XVII seredina XIX v. M.: Nauka, 1983. 206 s.

8. Leont'eva G.A. Sluzhilye lyudi v Vostochnoj Sibiri vo vtoroj polovine XVII - pervoj chetverti XVIII v. (po materialam Irkutskogo i Nerchinskogo uezdov). M., 2012. $321 \mathrm{~s}$.

9. Melikhov G.V. Man'chzhury na severovostoke Kitaya (XVII v.). Moskva: Nauka, 1974. $246 \mathrm{c}$.

10. Myasnikov V.S. Imperiya TSin i Russkoe gosudarstvo v XVII v. KHabarovsk: KHabarovskoe knizhnoe izdatel'stvo, 1987. $512 \mathrm{~s}$.

11. Russko-kitajskie otnosheniya $\mathrm{v}$ XVII veke: materialy i dokumenty. 1686-1691 / sost. N.F. Demidova, V.S. Myasnikov. M.: Nauka, 1972. T. 2. 835 s.

12. YAkovleva P.T. Pervyj russko-kitajskij dogovor 1689 goda. M.: Izdatel'stvo Akademii nauk SSSR, 1958. $213 \mathrm{~s}$. 